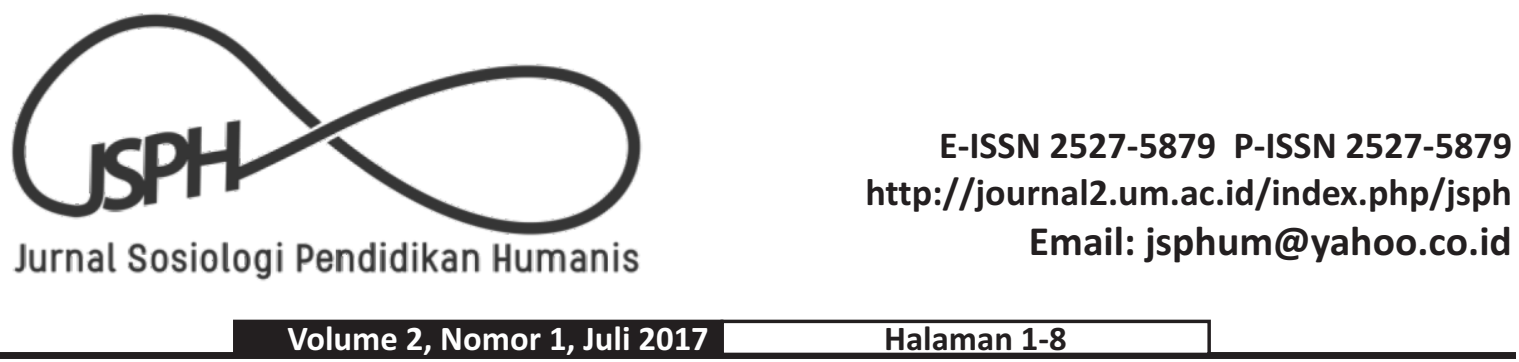

\title{
PENYELESAIAN SENGKETA RUANG HIDUP MASYARAKAT SUNDA WIWITAN DI KABUPATEN KUNINGAN
}

\author{
Gamin $^{1}$, Fati Lazira ${ }^{2}$ \\ ${ }^{1}$ Balai Diklat Lingkungan Hidup dan Kehutanan Kadipaten \\ ${ }^{2}$ Lembaga Bantuan Hukum Keadilan Bogor Raya (LBH KBR) \\ Email: gamingessa@gmail.com, fatilazira@gmail.com.
}

\begin{abstract}
Abstrak
Keterpinggiran masyarakat hukum adat di Indonesia masih disaksikan hingga saat ini padahal payung hukum untuk menguatkan posisi masyarakat adat telah ada dalam amandemen UUD 1945 dan Putusan MK No.35. Tulisan ini mengungkap faktor-faktor yang menjadi kelemahan masyarakat hukum adat dalam pengakuan hak-hak tenurial komunal dan mengidentifikasi upaya-upaya penguatannya. Kurang jelasnya wilayah adat, norma adat, anggota beserta tempat tinggalnya adalah faktor penting yang menjadi pertimbangan pengakuan formal dari pemerintah daerah. Ketiadaan pengakuan formal masyarakat hukum adat lambat laun akan mengurangi pengakuan (legitimasi) masyarakat adat tersebut di tengah-tengah kehidupan masyarakat. Untuk memperkuat posisi masyarakat hukum adat kiranya perlu memperkuat nilai/norma adat yang selama ini dipegang dan diatur adat. Selain itu membuktikan kepemilikan lahan dan wilayah adat serta mendefinisikan anggota masyarakat adatnya adalah penting untuk memperoleh pengakuan formal. Upaya menghindari kontak fisik antara pihak yang bersengketa penting dilakukan para pihak seraya berupaya menurunkan gaya sengketa yang dapat menerima pihak lain.
\end{abstract}

Kata Kunci: Masyarakat adat; ahli waris; AGATA

\section{SETTLEMENT OF DISPOSAL OF SUNDA WIWITAN COMMUNITY'S LIVING LIFE}

\begin{abstract}
The marginalization of indigenous and tribal peoples in Indonesia is still being witnessed on to this day whereas the legal umbrella to strengthen the position of indigenous peoples has existed in the 1945 amendments and the Constitutional Court Decree No.35. This paper is the factors that weaken indigenous and tribal peoples in the recognition of communal tenure rights and identify their strengthening efforts. The lack of clarity of customary territories, customary norms, members and their residences is an important factor in the consideration of formal recognition by local governments. The absence of formal recognition of indigenous and tribal peoples will gradually reduce the recognition (legitimacy) of these indigenous peoples in the midst of community life. To strengthen the position of customary law community, it is necessary to strengthen the customary values / norms that have been adhered to and adhered to. Furthermore, proving the ownership of customary lands and territories as well as defining members of indigenous peoples is essential to obtain formal recognition. Efforts to avoid physical contact between the parties to the dispute are important to the parties while trying to reduce the dispute style that can accept other parties.
\end{abstract}

Keywords: indigenous-community; comunal-property-right; AGATA 


\section{LATAR BELAKANG}

Masyarakat hukum adat di Indonesia diakui keberadaannya sebagai subyek hukum sejak UUD 1945 periode pertama. Pada bagian penjelasan UUD 1945 mengenai "persekutuan hukum rakyat" yaitu masyarakat hukum adat yang keberadaannya sebelum proklamasi kemerdekaan Republik Indonesia. Dalam penjelasan tersebut dinyatakan bahwa: "Dalam territoir Negara Indonesia terdapat lebih kurang 250 zelfbesturende landchappen dan volksgemenschappen, seperti desa di Jawa dan Bali, negeri di Minangkabau, dusun dan marga di Palembang dan sebagainya. Daerah-daerah itu mempunyai susunan asli, dan oleh karenanya dapat dianggap sebagai daerah yang bersifat istimewa. Negara Republik Indonesia menghormati kedudukan daerah-daerah istimewa tersebut dan segala peraturan negara yang mengenai daerah-daerah itu akan mengingati hak-hak asal-usul daerah tersebut."

Ketika dilakukan amandemen terhadap UUD 1945, bagian penjelasan UUD 1945 dihapus keberadaannya. Kemudian dasar hukum mengenai keberadaan masyarakat adat diletakkan pada Batang Tubuh UUD 1945. Setidaknya terdapat tiga ketentuan utama dalam UUD 1945 yang dapat menjadi dasar bagi keberadaan dan hak-hak masyarakat hukum adat. Tiga ketentuan tersebut yaitu Pasal 18B ayat (2), Pasal 28I ayat (3) dan Pasal 32 ayat (1) dan ayat (2) UUD 1945. Negara mengakui dan menghormati kesatuankesatuan masyarakat hukum adat serta hak-hak tradisonalnya sepanjang masih hidup dan sesuai dengan perkembangan masyarakat dan prinsip Negara Kesatuan Republik Indonesia, yang diatur dalam undang-undang (Pasal 18B (2) UUD 1945). Dalam pasal 28I ayat 3 disebutkan bahwa identitas budaya dan hak masyarakat tradisional dihormati selaras dengan perkembangan zaman dan peradaban. Negara juga memajukan kebudayaan nasional Indonesia di tengah peradaban dunia dengan menjamin kebebasan masyarakat daam memelihara dan mengembangkan nilai-nilai budayanya (Pasal 32 ayat 1 UUD 1945). Sementara pada ayat 2 pasal 32 UUD 1945 dinyatakan bahwa Negara menghormati dan memelihara bahasa daerah sebagai kekayaan budaya nasional.

Dalam konteks hukum agraria, masyarakat hukum adat diatur dalam UU No. 5 Tahun 1960 tentang Peraturan Dasar Pokok-pokok Agraria (UUPA). Dalam Pasal 2 ayat (4) UUPA disebutkan bahwa pelaksanaan hak menguasai dari negara dalam pelaksanaannya bisa dikuasakan kepada daerah-daerah Swatantra dan masyarakat-masyarakat hukum adat. Dalam hal ini masyarakat hukum adat bisa menerima delegasi kewenangan penguasaan negara atas bumi, air, ruang angkasa dan kekayaan alam. Jika ada bidang tanah yang dikuasai langsung oleh negara (tanah negara), termasuk yang berasal dari tanah bekas hak erfpact bahkan bekas hak guna usaha (HGU), penguasaannya dapat didelegasikan kepada masyarakat hukum adat, agar tujuan untuk sebesar-besar kemakmuran rakyat bisa dicapai. Kemudian penyebutan masyarakat hukum adat terdapat dalam pengaturan pengakuan keberadaan hak ulayat. Hal ini terdapat dalam Pasal 3 UUPA yang menyatakan bahwa pelaksanaan hak ulayat dan hak-hak yang serupa itu dari masyarakatmasyarakat hukum adat, sepanjang menurut kenyataannya masih ada, harus sedemikian rupa sehingga sesuai dengan kepentingan nasional dan negara, yang berdasarkan atas persatuan bangsa serta tidak boleh bertentangan dengan undangundang dan peraturan-peraturan lain yang lebih tinggi.

Kepemilikan tanah yang diatur dalam UUPA dikenal tujuh jenis hak atas tanah, yakni; hak milik, hak guna usaha, hak guna bangunan, hak pakai, hak sewa, hak membuka lahan dan hak memungut hasil hutan. Rezim kepemilikan dikelompokkan menjadi empat (Bromley, 1992) 1991). Pertama, rezim kepemilikan pribadi (private property regime), yakni kepemilikan pribadi atas sesuatu dimana hak atas sesuatu tersebut melekat pada pemiliknya, sehingga aturan berkenaan dengan sesuatu tersebut ditetapkan sendiri dan hanya berlaku untuk pemiliknya. Kedua, rezim kepemilikan bersama (common property regime), yakni kepemilikan oleh sekelompok orang tertentu dimana hak, kewajiban dan aturan ditetapkan dan berlaku untuk anggota kelompok tersebut. Ketiga, rezim kepemilkan oleh negara (state property regime), dimana hak kepemilikan dan aturan-aturannya ditetapkan oleh negara, individu tidak boleh memilikinya. Keempat, rezim akses terbuka, tidak ada aturan yang mengatur mengenai hak dan kewajiban.

Pada awal masa reformasi hak masyarakat adat atas lahan yang dibuat tergantung pada penatagunaan masih tidak jelas sehingga tidak dapat dinikmati oleh warganya . Pengakuan hak tenurial adat secara legal masih menjadi masalah ketika akan didaftarkan. Henley dan Davidson (2008) menyarankan pencatatan kepemilikan lahan berbasis desa dan mengenalkan blangko standar untuk pencatatan dan jual beli dapat mengurangi konflik agraria lebih baik daripada mendafarkan ke pusat yang lama dan berbiaya mahal. Posisi masyarakat adat Toraja di Sulawesi kuat dalam demokrasi adalah dengan menjaga dua hal, yakni nilai atau aturan adat dan pengakuan formal dari pemerintah lokal dalam kontek demokrasi. Amandemen UUD 1945 dan 
Putusan MK No.35 juga menjadi payung hukum untuk menguatkan posisi masyarakat adat.

Meskipun demikian, pengakuan formal hak tenurial komunal adat yang kuat masih belum mendapat bentuk yang tepat. Sebagai akibatnya keterpinggiran masyarakat hukum adat masih disaksikan hingga saat ini seperti terjadi di Maluku, Jambi, Barito Utara Kalimantan Tengah. Demikian juga yang terjadi pada Kesatuan Masyarakat Adat Karuhun Urang Sunda Wiwitan (Kesatuan Masyarakat AKUR Sunda Wiwitan), ruang hidupnya dirampas oleh pihak lain .Tanah milik adat Kesatuan Masyarakat AKUR Sunda Wiwitan dapat lepas kepemi-likannya dan dimiliki oleh individu melalui putusan pengadilan. Saling gugat kemudian terjadi hingga saat ini sehingga menjadi sengketa atau konflik agraria yang belum terselesaikan.

Konflik adalah suatu perwujudan perbedaan cara pandang antara berbagai pihak terhadap obyek yang sama. Konflik dipandang sebagai hubungan antara dua pihak atau lebih (individu atau kelompok) yang memiliki, atau merasa memiliki, sasaran-sasaran yang tidak sejalan (Fisher, Ludin, Williams, Abdi, Smith, \& Williams, 2001). Konflik adalah suatu situasi yang menunjukkan adanya praktik-praktik penghilangan hak seseorang atau lebih dan atau kelompok atas suatu benda atau kedudukan (Malik, Wijardjo, Fauzi, \& Royo, 2003). Berbeda lagi Pruitt dan Rubin bahwa konflik adalah persepsi mengenai perbedaan kepentingan (perceived divergence of interest), atau suatu kepercayaan bahwa aspirasi pihak-pihak yang berkonflik tidak dapat dicapai secara simultan (Pruitt \& Rubin, 1986). Suatu konflik sosial terjadi ketika dua atau lebih orang atau kelompok menyatakan keyakinannya bahwa mereka mempunyai tujuan-tujuan yang tidak berkesesuaian (Kriesberg, 1998). Sedangkan (Suporahardjo, 2000) menjelaskan bahwa konflik adalah benturan yang terjadi antara dua pihak atau lebih, yang disebabkan adanya perbedaan nilai, status, kekuasaan, dan kelangkaan sumberdaya. Pada tulisan ini digunakan definisi sesuai Suporaharjo (2000).

Mengapa kekalahan masyarakat adat kerap berulang merupakan isu yang menarik untuk diungkap penyebab-penyebabnya. Faktor-faktor yang membuat pihak lain memenangkan kompetisi atas masyarakat adat terkait lahan layak untuk dipelajari. Upaya-upaya yang mungkin dapat dilakukan untuk memperkuat posisi masyarakat adat tersebut penting untuk ditempuh. Apa alternatif penyelesaian sengketa di luar pengadilan yang tepat dipilih guna menghindari saling gugat yang tiada akhir.

\section{METODE PENELITIAN}

Sudut pandang kualitatif (Sugiyono, 2010) dipilih untuk menginterpretasikan fenomena yang terjadi pada tulisan ini. Pengumpulan data dilakukan dengan teknik observasi dan wawancara mendalam (Cavestro, 2003). Penentuan informan dilakukan dengan metode bola salju (Sugiyono, 2010). Analisis penyelesaian sengketa ruang hidup masyarakat Sunda Wiwitan ini dicermati menggunakan perangkat Analisis Gaya Bersengketa (Sirait, 2011). Penelitian dilakukan sejak bulan Mei hingga Juli 2017 ketika kasus perlawanan pengadilan masih berjalan. Studi kasus (Yin, 1996) pada Masyarakat AKUR Sunda Wiwitan ditulis untuk memperoleh gambaran dari masalah penelitian tersebut. Obyek sengketa yang pada masyarakat AKUR adalah sebidang tanah darat dengan bangunan yang secara administratif terletak di Blok Mayasih, RT. 29/10, Kelurahan Cigugur, Kecamatan Cigugur, Kabupaten Kuningan, Jawa Barat. Secara geografis tanah tersebut berada pada sekitar $6^{\circ} 58^{\prime} 7.34 "$ Lintang Selatan dan $108^{\circ} 27^{\prime} 21.87$ Bujur Timur.

\section{HASIL DAN PEMBAHASAN}

\section{Sejarah Kesatuan Masyarakat Adat Karuhun Urang (AKUR) Sunda Wiwitan}

Kesatuan Masyarakat Adat Karuhun Urang (AKUR) Sunda Wiwitan, berasal dari masyarakat adat yang dibentuk oleh Pak Sadewa Madrais Alibassa Kusumah Wijaya Ningrat. Ia memaparkan ajaran Igama Djawa Pasoendan, dan oleh pemerintah Hindia Belanda diakui keberadaannya pada tahun 1885 .

Pada awal kemerdekaan Indonesia hingga tahun 1964, ajaran Igama Djawa Pasoendan lebih dikenal dengan Agama Djawa Sunda (ADS), menjadi anggota dari organisasi Badan Kongres Kebatinan Indonesia. Karena situasi politik nasional, organisasi ADS membubarkan diri pada tahun 1964 namun masyarakat adatnya masih menjalankan tradisi leluhurnya.

Pada tahun 1981 Komunitas adat mengikatkan diri dan diinventarisir di Kementerian Pendidikan dan Kebudayaan dengan nama menjadi Paguyuban Adat Cara Karuhun Urang (PACKU). Seiring dengan

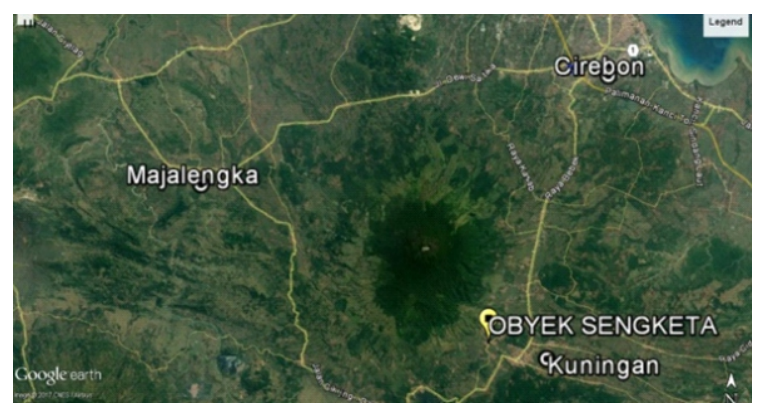

Gambar 1. Lokasi Sengketa 
dinamika yang terjadi dimasyarakat, PACKU berubah menjadi Kesatuan Masyarakat Adat Karuhun Urang (AKUR) Sunda Wiwitan pada tahun 1996 sampai dengan sekarang.

Pak Sadewa Madrais Alibassa Kusumah Wijaya Ningrat semasa hidupnya banyak membuat Manuskrip/ Nawala. Ia juga banyak menulis tentang ajarannya termasuk wasiat mengenai tanah-tanah dan bangunan yang diperuntukan sebagai milik komunal Masyarakat Adat, yang dalam hal ini Masyarakat Adat AKUR Sunda Wiwitan. Di dalam manuskrip tersebut dituliskan bahwa keturunan tidak mendapatkan pembagian waris. Adapun tanah-tanah dan bangunan memang diperuntukkan untuk Masyarakat Adat guna melestarikan ajaran kebudayaan untuk kepentingan bangsa.

Setelah Pak Madrais meninggal dunia pada tahun 1939 kemudian digantikan oleh anaknya, yaitu Pak Tedjabuwana Alibassa. Pada masa Pak Tedjabuwana, tanah-tanah peninggalan Pak Madrais, pada tahun 1941 diatasnamakan menjadi Pak Tedjabuwana, hal tersebut tercantum didalam Kekitir Padjeg Boemi.

Walaupun tanah-tanah dan bangunan peninggalan Pak Madrais telah dibalik nama menjadi atas nama Pak Tedjabuwana Alibassa, namun tanah-tanah dan bangunan yang telah diatasnamakannya tidak dapat diwariskan kepada ahli waris maupun keturunannya.

Sikap tegas Pak Tedjabuwana tersebut dikarenakan adanya pesan atau amanat dari Pak Madrais baik secara lisan maupun tertulis di dalam Manuskrip. Sikap tegas tersebut dipegang teguh oleh seluruh anak dan keturunannya Pak Madrais maupun PakTedjabuwana.

Pada tanggal 05 April 1978, Pak Tedjabuwana wafat. Kedudukan atau posisi dari Pak Tedjabuwana digantikan oleh Pak Djatikusumah selaku Kepala Adat atau Sesepuh Adat sampai salah seorang seorang keturunan Pak Tedjabuwana bernama Raden Djaka Rumantaka mengklaim bahwa ada sebidang tanah yang merupakan hak waris daripada ibunya. Raden Djaka Rumantaka kemudian mengajukan gugatan atas tanah darat yang terletak di Blok Mayasih, RT. 29/10 Kelurahan Cigugur, Kecamatan Cigugur, Kabupaten Kuningan, Jawa Barat.
Tanah tersebut tercatat dalam buku letter $\mathrm{C}$ Nomor: 2321 persil 78a kelas D.I luas \pm 224 M2 (16 bata) atas nama Ratu Siti Djenar Alibassa Almarhum. Obyek tanah seluas \pm 224 M2 (16 bata) tersebut adalah sebagian dari jumlah keseluruhan tanah yang tercantum dalam Letter C, seluas $6210 \mathrm{~m} 2$ atas nama Pak Tedja Buana, ditempati oleh Kusnadi dan K Mimin S sejak tahun 1973).

Pada tahun 2009, Raden Djaka Rumantaka (Penggugat) mengajukan Gugatan Perbua- tan Melawan Hukum melalui Pengadilan Negeri Kuningan melawan Kusnadi dan K. Mimin S sebagai tergugat I dan tergugat II serta turut tergugat I, II, III, dan IV secara berurut atas nama Raden Dadang Andaru Andaroso, Raden Iksan Titop Purworsucipto, Raden Lina Djuarningsing dan BPN Kabupaten Kuningan.

Atas gugatan tersebut, Raden Djaka Rumantaka sebagai Penggugat telah memenangkan gugatan dan atas nya telah memiliki kekuatan hukum mengikat, sehingga secara yuridis - normatif, objek sengketa dalam gugatan dapat dieksekusi, kecuali ada hal-hal tertentu yang dapat menunda atau menangguhkan eksekusi.

Seiring dengan kemenangan pihak Raden Djaka Rumantaka itu, pihak Pak Djatikusumah selaku Kepala Adat Kesatuan Masyarakat Adat Karuhun Urang (AKUR) Sunda Wiwitan mengajukan gugatan perlawanan atas putusan yang telah berkekuatan hukum tetap tersebut di Pengadilan Negeri Kuningan. Pihak terlawan dalam hal ini adalah: 1). Raden Dadang Andaru Andaroso, Raden Iksan Titop Purworsucipto, Raden Lina Djuarningsing; 2). Kusnadi; 3).Ibu K. Mimin S; 4). Badan Pertahanan Nasional; 5). Lurah Kantor Cigugur; dan 6). Camat Kecamatan Cigugur.

Pada sidang pertama pada 5 Juli 2017 ini pihak terlawan 2, 5, dan 6 tidak hadir. Pada sidang I, II, dan III yang diagendakan dalam kurun waktu 3 (tiga) bulan sebelumnya tidak pernah terlaksana karena semua pihak terlawan tidak hadir. Sidang pada 5 Juli 2017 tersebut mengagendakan upaya mediasi yang dilaksanakan pada 12 Juli 2017.

\begin{tabular}{clll}
\hline & \multicolumn{3}{c}{ Pesengketa utama } \\
\hline Nama & \multicolumn{1}{c}{ Kedudukan } & Peran dalam sengketa & \multicolumn{1}{c}{ Bukti Klaim } \\
\hline Raden Djaka & satu keturunan Pak & pengklaim serta & Keterangan ahli waris, \\
& Tedjabuwana & pemenang sengketa & Bukti kepemilikan tanah \\
\hline Pak Djati & turunan ketiga dari & selaku Kepala Adat & Rumah Cagar Budaya, \\
& pendiri Kesatuan & Kesatuan Masyarakat & pesan atau amanat dari Pak Madrais baik \\
& Masyarakat Adat & Adat Karuhun Urang & secara lisan maupun tertulis di dalam \\
& Karuhun Urang & (AKUR) Sunda Wiwitan. & Manuskrip \\
& (AKUR) Sunda & & \\
& Wiwitan. & & \\
\hline
\end{tabular}




\section{Pihak Bersengketa}

Para pihak utama yang bersengketa pada kasus ini adalah Rd. Djaka Rumantaka salah satu keturunan Pak Tedjabuwana selaku pengklaim serta pemenang sengketa dan Pak Djatikusumah turunan ketiga dari pendiri selaku Kepala Adat Kesatuan Masyarakat Adat Karuhun Urang (AKUR) Sunda Wiwitan (Lihat Tabel 1).

Sengketa antara Raden Djaka Rumantaka dan Pak Djatikusumah selaku Kepala Adat Kesatuan Masyarakat AKUR Sunda Wiwitan atas obyek sengketa melibatkan 1). Raden Dadang Andaru Andaroso, Raden Iksan Titop Purworsucipto, Raden Lina Djuarningsing; 2). Kusnadi; 3).Ibu K Mimin S; 4). Badan Pertahanan Nasional; 5). Lurah Kantor Cigugur; dan 6). Camat Kecamatan Cigugur. Kedududukan para pihak memiliki peran tersendiri dalam sengketa ini. 1). Raden Dadang Andaru Andaroso, Raden Iksan Titop Purworsucipto, Raden Lina Djuarningsing; 2).Kusnadi; 3).Ibu K Mimin S berperan sebagai penghuni rumah dan tanah yang disengketakan; 4). Badan Pertahanan Nasional sebagai pengadministrasi pertanahan berperan mengeluarkan surat titel atas tanah dan mengadministrasikannya; 5). Lurah Kantor Cigugur sebagai pimpinan tertinggi di kelurahan berperan mengeluarkan kete-rangan ahli waris bagi Raden Djaka Rukmantaka; dan 6). Camat Kecamatan Cigugur sebagai atasan Lurah Cigugur berperan dalam administrasi pertanahan.

\section{Gaya Sengketa Para Pihak}

Dalam menyikapi persoalan para pihak memiliki kecenderungan terhadap sengketa yang dihadapi. Kecenderungan para pihak yang bersengketa pada kasus ini sama-sama menempatkan diri pada gaya kompetisi (lihat gambar 2). Hal ini dilakukan karena masing-masing pihak merasa memiliki kekuatan klaim yang cukup untuk memenangkan klaimnya.

Raden Djaka Rumantaka memiliki bukti klaim

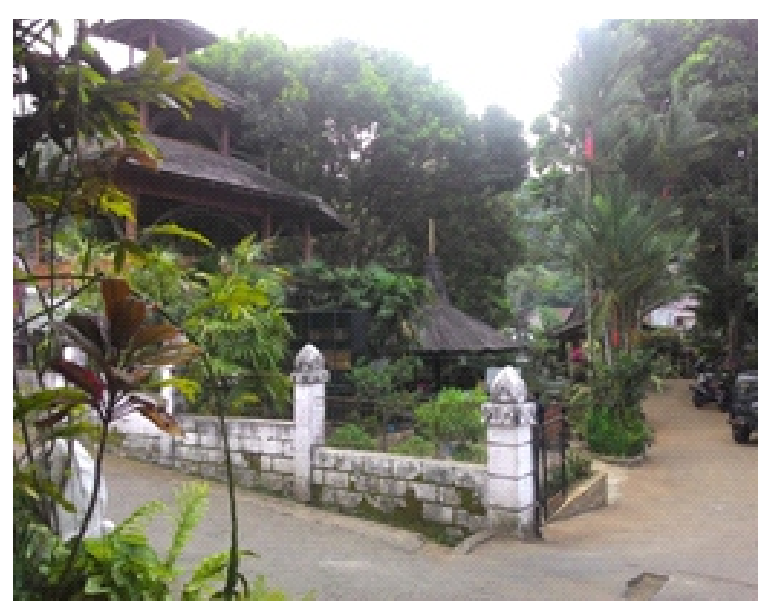

Gambar 2. Rumah Cagar Budaya Masyarakat AKUR berupa keterangan Lurah bahwa RadenDjaka Rukmantaka adalah keturunan Pak Tedjabuwana dan surat keterangan tanah dari Badan Pertahanan Nasional atas dasar surat keterangan dari Lurah dan Camat Cigugur.

Pihak Pak Djatikusumah selaku Kepala Adat Kesatuan memiliki bukti klaim berupa Rumah Cagar Budaya yang masih dihuni keluarganya beserta benda peninggalannya, penuturan lisan dan Manuskrip dari P. Madrais yang menyatakan bahwa tanah Kesatuan Masyarakat AKUR Sunda Wiwitan tidak dapat dibagikan kepada perorangan sekalipun keturunannya.

\section{Kedudukan Masyarakat Adat Menurut Peraturan Perundangan}

Kedudukan masyarakat hukum adat merupakan subyek hukum khusus yang keberadaannya harus memenuhi kriteria-kriteria yang telah ditetapkan oleh peraturan perundangundangan. Beberapa perbedaan mengenai kriteria kesatuan masyarakat hukum adat dalam sejumlah peraturan perundang-undangan sebagaimana telah dikemukakan di atas. Ragam kriteria kesatuan masyarakat hukum adat yang berbeda antara satu undang-undang dan undangundang lain. Semua kriteria tersebut sebenarnya merupakan penjabaran lebih lanjut dari Pasal 18B Ayat (2) UUD 1945.

Kriteria lain ditemukan di dalam Putusan Mahkamah Konstitusi dalam Perkara No. 31/PUU-V/2007 mengenai Pengujian UU No. 31 Tahun 2007 tentang Pembentukan Kota Tual di Provinsi Maluku. Dalam putusan tersebut Mahkamah Konstitusi menafsirkan maksud dari tiga syarat pengakuan keberadaan masyarakat adat di dalam Pasal 18B ayat (2) UUD 1945 dan Pasal 51 ayat (1) UU Mahkamah Konstitusi dengan kriteria: 1). ada masyarakat yang warganya memiliki perasaan sebagai satu kelompok karena adanya nilai-nilai yang dirawat

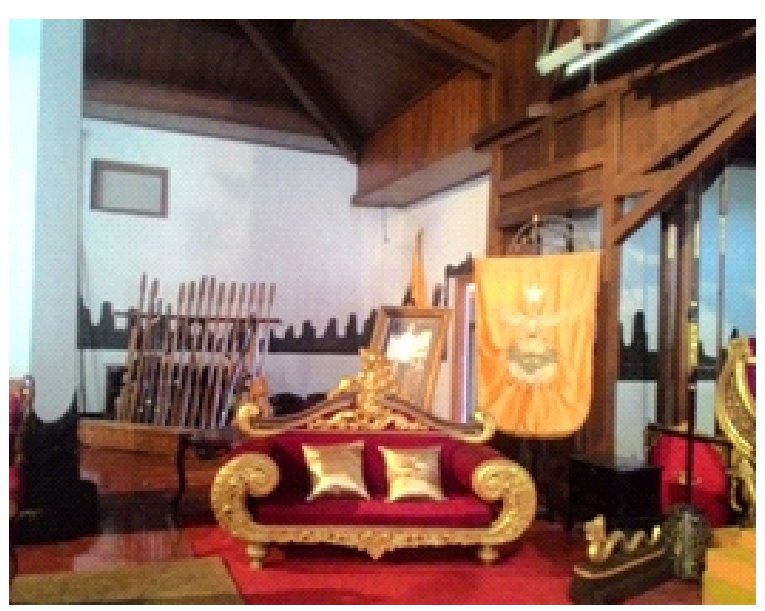

Gambar 3. Benda Bersejarah Masyarakat AKUR 
secara bersama-sama; 2). ada lembaga adat yang tumbuh secara tradisional; 3). ada harta kekayaan dan/atau benda-benda adat; 4). ada norma hukum adat yang masih berlaku; dan 5). ada wilayah adat tertentu.

Dengan demikian, maka berdasarkan putusan Mahkamah Konstitusi terdapat lima kriteria kesatuan masyarakat hukum adat yaitu ada masyarakatnya, ada lembaga adatnya, ada harta kekayaan bersama, ada norma hukum adatnya, dan ada wilayah tempat keberadaannya (lihat gambar 3). Suatu kesatuan masyarakat hukum adat yang memenuhi kelima kriteria itu berkedudukan sebagai subyek hukum dan oleh karenanya memiliki hak dan kewajiban yang dapat dipertanggungjawabkan secara hukum. Selain itu, putusan Mahkamah Konstitusi tersebut menjelaskan mengenai sifat kesatuan masyarakat hukum adat dalam tiga karakter, yaitu genalogis, territorial, dan fungsional. Sifat genealogis artinya suatu kesatuan masyarakat hukum adat terikat karena satu asal usul keturanan atau pertalian dasar. Sifat territorial menekankan kepada kesamaan wilayah tempat tinggal. Sementara itu sifat fungsional berarti kesatuan masyarakat hukum adat tersebut masih menjalankan fungsi-fungsi sosialnya melalui lembaga adat. Kesatuan masyarakat hukum adat dapat bersifat genealogis dan teritoral, tetapi juga bisa bersifat genalogis, territorial dan fungsional. Kesatuan masyarakat hukum adat dengan sifat genealogis, territorial dan fungsional dapat ditetapkan sebagai desa adat berdasarkan UU No. 6 Tahun 2014 tentang Desa.

\section{Faktor-faktor Kekuatan dan Kelemahan Para Pihak}

Sumber-sumber kekuatan klaim yang Rd. Djaka Rukmantaka selama ini dapat digunakan untuk melakukan gugatan dan memenangkannya di Pengadilan Negeri Kuningan namun kemudian perlawanan dilakukan pihak Pak Djatikusumah karena dinilai memiliki kelemahan. Pihak Pak Djatikusumah merupakan keturunan dan Ketua Adat yang sah menurut adat namun anggota dan wilayah Masyarakat Hukum Adatnya cenderung menyebar. Posisi hukum Masyarakat Hukum Adatnya juga belum memperoleh pengakuan dari pemerintah daerah setempat (lihat tabel 2).

\section{Upaya-upaya memperkuat posisi Masyarakat AKUR Sunda Wiwitan}

Posisi masyarakat AKUR Sunda Wiwitan yang terasa semakin terpinggirkan dapat dikuatkan dengan memperkuat nilai/norma adat (Yunus and Tamma 2014) yang selama ini dipegang dan diatur adat. Menelusuri bukti-bukti kepemilikan dan keanggotaan masyarakat adatnya penting dilakukan (Yunus \& Tamma, 2014). Hal ini penting dilakukan untuk mempertahankan keberadaannya guna memperoleh pengakuan pemerintah daerah sesuai peraturan perundangan yang ada.

Melihat gaya bersengketa para pesengketa utama yang memilih kompetisi, maka perlu dijaga agar kompetisi yang dilakukan bersifat konstuktif untuk memperoleh kebaikan struktural. Upaya untuk menghin-dari kompetisi konstruktif, kontak fisik, yang menimbulkan

\begin{tabular}{|c|c|c|}
\hline \multicolumn{3}{|c|}{ Tabel 2. Kekuatan dan kelemahan para pihak } \\
\hline Pihak & Kekuatan & Kelemahan \\
\hline \multirow{5}{*}{$\begin{array}{l}\text { Raden Djaka } \\
\text { Rukmantaka }\end{array}$} & Memiliki keterangan Waris Pak Tedjabuwana & Diduga pembuatannya tidak melibatkan Pak \\
\hline & yang diperoleh dari Lurah & Djatikusumah sebagai Kepala Adat yang sah \\
\hline & Memiliki surat bukti tanah & $\begin{array}{l}\text { Diduga surat bukti tanah diterbitkan berdasarkan } \\
\text { keterangan sebagai ahli waris yang tidak diakui pihak P. } \\
\text { Djatikusumah }\end{array}$ \\
\hline & $\begin{array}{l}\text { Surat tanah merupakan milik individu dan ada } \\
\text { informasi akan dijual }\end{array}$ & $\begin{array}{l}\text { Dalam manuskrip dari Pak Madrais yang dipatuhi Pak } \\
\text { Teja dan P. Djati disebutkan bahwa tanah adat AKUR } \\
\text { Sunda Wiwitan tidak dapat dibagikan kepada ahli waris. }\end{array}$ \\
\hline & $\begin{array}{l}\text { Telah memenangkan gugatan dan berkekuatan } \\
\text { hukum tetap untuk dieksekusi kecuali ada } \\
\text { penghalang yang berarti. }\end{array}$ & $\begin{array}{l}\text { Ada perlawanan dari pihak Pak Djatikusumah yang } \\
\text { menyatakan obyek sengketa adalah tanah adat. }\end{array}$ \\
\hline \multirow[t]{5}{*}{$\begin{array}{l}\text { Pihak Pak } \\
\text { Djatikusumah }\end{array}$} & $\begin{array}{l}\text { Merupakan keturunan dan Ketua Adat yang sah } \\
\text { menurut adat }\end{array}$ & Wilayah adat Sunda Wiwitan tidak jelas batasnya \\
\hline & $\begin{array}{l}\text { Masih memiliki rumah adat, padepokan yang } \\
\text { diresmikan menjadi Cagar Budaya }\end{array}$ & Terkesan kurang pengakuan dari Pemerintah Daerah \\
\hline & $\begin{array}{l}\text { Memiliki aturan / norma adat seperti Upacara } \\
\text { Seren Taun }\end{array}$ & \\
\hline & $\begin{array}{l}\text { Masih ada anggota masyarakat AKUR Sunda } \\
\text { Wiwitan }\end{array}$ & $\begin{array}{l}\text { Anggota masyarakat adatnya sudah tidak mengelompok } \\
\text { pada suatu wilayah }\end{array}$ \\
\hline & $\begin{array}{l}\text { Sudah diakui pemerintah Pusat periode presiden } \\
\text { Gusdur }\end{array}$ & $\begin{array}{l}\text { Belum mendapatkan pengakuan dari Pemerintah Daerah } \\
\text { dalam bentuk Perda }\end{array}$ \\
\hline
\end{tabular}


kerusakan sebaiknya dijaga semua pihak. Langkah berikutnya yang dapat dilakukan adalah upaya penurunan ketegan-gan (de-eskalasi) kepada masing-masing pihak dengan mengingat kelemahan pihak sendiri dan kekuatan pihak lain sehingga sikapnya berubah untuk menerima sebagian keinginan pihak lain demi perdamaian dan keharmonisan hubungan berikutnya.

\section{KESIMPULAN}

Kurang jelasnya wilayah adat, norma adat, anggota beserta tempat tinggalnya adalah faktor penting yang menjadi pertimbangan pengakuan formal dari pemerintah daerah. Ketiadaan pengakuan formal masyarakat hukum adat lambat laun akan mengurangi pengakuan (legitimasi) masyarakat adat tersebut di tengah-tengah kehidupan masyarakat.

Untuk memperkuat posisi masyarakat hukum adat kiranya perlu memperkuat nilai/norma adat yang selama ini dipegang dan diatur adat. Selain itu membuktikan kepemilikan lahan dan wilayah adat serta mendefinisikan anggota masyarakat adatnya adalah penting untuk memperoleh pengakuan formal. Upaya menghindari kontak fisik antara pihak yang bersengketa penting dilakukan para pihak seraya berupaya menurunkan gaya sengketa yang dapat menerima pihak lain.

\section{DAFTAR RUJUKAN}

Bromley, D. (1992). Making The Commons Work. Theory, Practice and Policy. California (US): ICS Press Institut for Contemporary Studies San Francisco.

Cavestro, L. (2003). P.R.A. Participatory Rural Appraisal Concepts Methodologies and Techniques. Rome: Universita' Degli Atudi Di Padova, Facolta' Di Agraria, Dipartimento Terrirorio E Sistemi AgroForestali. Master In Cooperazione Allo Sciluppo Nelle Aree Rurali.

Fisher, S., Ludin, J., Williams, S., Abdi, D., Smith, R., \& Williams, S. (2001). Mengelola Konflik: Keterampilan \& Strategi untuk bertindak. Kartikasari SN, MD Tapilatu, $R$ Maharani, dan DN Rini, penerjemah; Kartikasari SN, editor. . Jakarta (ID): The British Council.

Kriesberg, L. (1998). Constructive Conflicts From Escalation to Resolution. Maryland, USA (US): Rowman \& Littlefield Publisher, Inc.

Li, T. M. (2001). Masyarakat Adat, Difference, and the Limits of Recocnition in Indonesia's Forest Zone. Modern Asian Studies, 35(3), 645-676.
Malik, I., Wijardjo, B., Fauzi, N., \& Royo, A. (2003). Menyeimbangkan Kekuatan Pilihan Strategi Menyelesaikan Konflik atas Sumberdaya Alam. Jakarta (ID): Yayasan Kemala.

Pruitt, D., \& Rubin, J. (1986). Teori Konflik Sosial [Soetjipto HP, Soetjipto SM, Penterjemah]. Dari : Social Conflict Escalation, Stalemate, and Settlement. McGraw-Hill, Inc. Yogyakarta (ID): Pustaka Pelajar.

Putro, Y. H. (2014, Mei 08). Kalah di Pengadilan, Warga Adat Semende Tetap Bertahan di Hutan. Retrieved Juli 19, 2017, from h t t p : / / n e w s. 1 i put a n 6 . c o m : http://news.liputan6.com/read/2047056/k alah-di-pengadilan-warga-adat-semendetetap-bertahan-di-hutan

Ranik, E. S. (2003). Gugatan Masyarakat Adat Kalah di Pengadilan. PT. IMK terbukti menggusur lubang tambang, tetapi bebas dari kewajiban ganti rugi. Retrieved Juli 19, 2017, from http://www.downtoearthindonesia.org http://www.downtoearthindonesia.org/id/story/gugatan-masyarakat-adat-kalah-di-pengadilan

Sirait, G. P. (2011). Analisa Gaya BersengketaAGATA. Panduan Ringkas untuk Membantu Memilih Bentuk Penyelesaian Sengketa Pengelolaan Sumberdaya Alam. Bogor: Samdhana Institute.

Sugiyono. (2010). Memahami Penelitian Kualitatif. Bandung: Alfabeta.

Suporahardjo. (2000). Inovasi Penyelesaian Sengketa Pengelolaan Sumber Daya Hutan. . Bogor (ID): Pustaka LATIN.

Tim Pembela Kesatuan Masyarakat AKUR Sunda Wiwitan. (2017, Mei 30). Siaran Pers Tim Pembela Kesatuan Masyarakat AKUR Sunda Wiwitan. Perampasan Ruang Hidup Masyarakat Adat Sunda Wiwitan (Bagian 1). Retrieved Juli 19, 2017, from http://www.findglocal.com: http://www.findglocal.com/ID/Jakarta/66 8695293269863/Perhimpunan-PembelaMasyarakat-Adat-Nusantara

Topatimasang, R. (2004). Orang-orang Kalah: Kisah Penyingkiran Masyarakat Arat Kepulauan Maluku. Yogyakarta: INSIST Press.

Wulan, Y., Yasmi, Y., Purba, C., \& E, E. W. (2004.). Analisa Konflik Sektor Kehutanan di Indonesia 1997-2003. . Bogor (ID): CIFOR.

Yin, R. K. (1996). Studi Kasus, Deasin \& Metode. Jakarta: PT. Raja Grafindo Persada. 
Jurnal Sosiologi Pendidikan Humanis Volume 2, Nomor 1, Juli 2017

Yunus, R., \& Tamma, S. (2014, Januari). Importance of Cultutal Legitimacy to the Local Government in Indonesia Democracy. International Journal of Administrative Science \& Organization, Bisnis \& Birokrasi, Jurnal Ilmu Administrasi dan Organisasi, 21(1), 28-34. 